\title{
Remobilizing stabilized island dunes for keeping up with sea level rise?
}

\author{
Felix Osswald $^{1,2}$ (D) Tobias Dolch $^{1} \cdot$ Karsten Reise $^{1}$ \\ Received: 1 August 2018 /Revised: 30 April 2019 / Accepted: 3 May 2019 / Published online: 17 May 2019 \\ (C) The Author(s) 2019
}

\begin{abstract}
Dune spits of the island of Sylt (North Sea) persisted through millennia by mobile dunes transferring sand from exposed to sheltered shores. However, 150 years of systematic planting on washovers, blowouts and migrant dunes have almost completely stopped this sand conveyor belt. Spits lost sand until sand replenishments to the exposed side compensated for losses during the last three decades. Based on maps since 1878, aerial images from the 1930s onward as well as botanical ground surveys, we document a long-term shift from loose grass cover to dense heather dominated vegetation. Bare sand areas almost vanished and high shrubs proliferated. Only three dunes continue migrating with about $3 \mathrm{~m} \mathrm{a}^{-1}$ since 1936 . Mainly artificial dune stabilizations and introduced plants have facilitated succession to an almost complete plant cover. Thus, revitalization of aeolian dynamics would be desirable, and pilot projects may acquire the appropriate knowledge. For a $1.7 \times 2.5-\mathrm{km}$ corridor across the island spit, we therefor discuss two suggested experiments: (1) intensify sand nourishments to the eroding beach and stop stabilization measures to allow excess sand blown inland and washovers entering deflation plains, and (2) examine the potential of tunnels for roads to let mobile dunes passing over. Such experiments may not only contribute to dune biodiversity but also to long-ranging adaptations of crowded barrier islands to accelerating sea level rise.
\end{abstract}

Keywords Barrier island $\cdot$ Dune dynamics $\cdot$ Habitat mapping $\cdot$ North Sea $\cdot$ Sand nourishment $\cdot$ Sea level rise

\section{Introduction}

Globally, more than two thirds of coastal beaches are eroding (Bird 1987), and this will exacerbate with global warming (Zhang et al. 2004). Behind eroding sandy shores, transgressive dune fields often develop (Hesp 2013). In NW-Europe, livestock grazing, introduced rabbits, clearing wood, harvesting dune vegetation and sod-cutting have facilitated aeolian activity of these dunes for centuries (Provoost et al. 2011).

However, since the nineteenth century more and more of these dunes became stable. Dune stabilization programs intended to prevent damage to and burial of arable land, hous-

Felix Osswald

felix.osswald@uni-oldenburg.de

1 Alfred-Wegener-Institute, Helmholtz Centre for Polar and Marine Research, Wadden Sea Station Sylt, Hafenstr. 43, 25992 List, Germany

2 Carl von Ossietzky University Oldenburg, Ammerländer Heerstr. 114-118, 26129 Oldenburg, Germany es and roads. Furthermore, upcoming coastal tourism substituted for income from livestock grazing in the dunes. In addition, rabbit diseases and anthropogenic nitrogen deposition increased vegetation cover again. In combination, these effects reduced aeolian dynamics and stabilized many dunefields (Provoost et al. 2011).

Recently, a paradigm shift in coastal dune management is discussed (Arens et al. 2013; de Groot et al. 2017b; Martínez et al. 2013; Oost et al. 2012; Psuty and Silveira 2013). Restoring former morphodynamics should both reverse decreasing dune biodiversity and increase their adaptive capacity to adjust to an accelerating sea level rise in the future. However, at coasts with high real estate prices, a return to coastal dynamics constitutes a challenge (Döring and Ratter 2018; Hofstede and Stock 2018; Oost et al. 2012).

The transgressive dune field on the island of Sylt in the eastern North Sea experiences the consequences of stabilization, too. Here, Priesmeier (1970) more than 50 years ago already pointed to a long-term negative sand mass balance due to dune stabilizations, confounding attempts of coastal protection. Based on map-transformed aerial photographs from 1925 and 1965, which he combined with analyses of 
dune morphodynamics, Priesmeier proposed a qualitative sand balance model for the northern sandy hook of the island.

We here review his model because it was published in German and in a regional journal which now is difficult to access. Unlike adjacent barrier islands originating from sand bars, the position of the island of Sylt is further offshore due to a core of glacial deposits. This core is subject to permanent shoreline erosion. Longshore sand transport created two long sandy spits attached to the core, one to the south and one to the north (Fig. 1a; Ahrendt and Thiede 2002; Gripp and Simon 1940). Core and spits retreated by 1 to $2 \mathrm{~m}$ annually. Priesmeier (1970) assumed a partial loss of sand to the sea. The majority of the sediment, though, was blown onto the island by the prevailing westerly winds, where they form mobile parabolic dunes and large mobile dunes. These dunes migrate from west to east, until they reached sheltered tidal flats (Fig. 1b). Priesmeier measured that annual dune migration rates are about $3.75 \mathrm{~m}$. This exceeded shoreline retreat, resulting in a conveyor belt transporting sand from the highly exposed North Sea beach to the more sheltered beach on the other side of the island. There, another longshore current dissipated dune sand into a tidal basin, located between island and mainland.
Priesmeier's model (Fig. 1b) suggests that over the past 6,000 years of spit existence, generations of migrant dunes balanced sediment loss at the western shore with accretion at the eastern shore. This has been confirmed by recent investigations (Lindhorst et al. 2008). Concerted dune stabilizations carried out on the island since the 1860 s tended to interrupt the inferred sand conveyor belt. According to Priesmeier (1970), in the long-term this would be counterproductive from a coastal defence perspective. However, coastal managers either took no notice of Priesmeier's study or decided to give priority to dune stabilizations for the short-term benefit of saving infrastructures built on the dune spits. Anyway, the sand conveyor belt waned.

Since Priesmeier (1970), two developments came up which require renewed attention to his sand balance model: (1) In the wake of global warming by anthropogenic greenhouse gas emissions, sea level rises faster than before (Nerem et al. 2018), and (2), since the 1980s regular sand replenishments compensated shoreline retreat at the island of Sylt (Hofstede and Stock 2018). Therefore, we decided to extend the 1925 to 1965 comparison of the dune landscape by Priesmeier (1970) to 2012. Furthermore, we included a map from 1878. Based on this long-term comparison, we ask: (1) How has dune

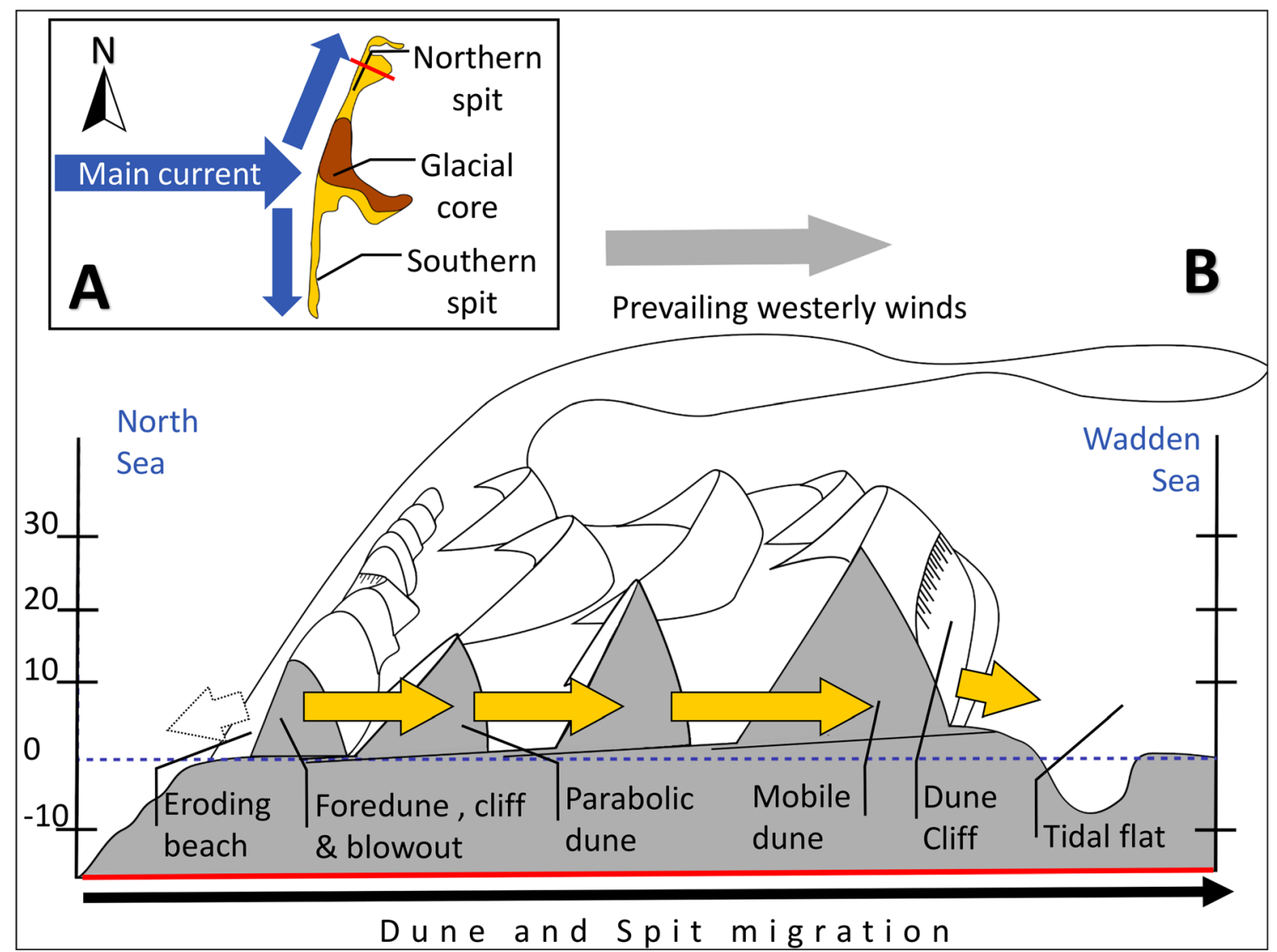

Fig. 1 Schematic overview of Priesmeier's (1970) sand conveyor belt model. Beach erosion only relocates sediment into the nearshore area. The prevailing westerly winds transport the greater share as overwash and parabolic dunes across the spit. On their journey, the parabolic dunes may merge into larger and faster mobile dunes, which eventually erode at the eastern beach. A: Island of Sylt. Red line indicates transect shown in $\mathrm{B}$, where arrows refer to aeolian sand transport 
migration proceeded, (2) how has vegetation cover changed, and (3) what have been the drivers affecting dune development and vegetation up to now?

Our purpose is to contribute to the challenge of adapting barrier islands to the accelerating rise of the sea and maintaining sand dune and vegetation diversity at the same time. Thus, we combine our long-term analysis with suggestions for a sustainable dune management.

\section{Study area and methods}

At the northern spit of Sylt, three transgressive dunes still migrate from west to east (Fig. 2). Migration rates are calculated by comparing positions of the steep white slip sides of migrant dunes meeting dark deflation plain vegetation in aerial photographs from 1936 to 2012, with intermediate images from 1958, 1965, 1988, 1998 and 2006. This tends to provide a rather sharp line of high contrast. In addition, topographic maps from 1878 (Königlich Preußische Landesaufnahme 1878) and 1925
(Priesmeier 1970) have been used for analysis, although their accuracy may be lower.

Our selected study area reaches from the exposed beach on the North Sea side, across a chain of primary foredunes and a transgressive dunefield comprising parabolics, static and active transgressive dunes with long trailing ridges in wide deflation plains with gegenwalle, and a sheltered beach with tidal flats on the Wadden Sea side (Figs. 1, 2 and 3). While the transgressive dune belts moved with the prevailing winds from west to east, the gegenwalle emerged during easterly winds and do not move. According to Priesmeier (1970) new belts of transgressive dunes formed about every 300 years near the western shore. Most likely, exceptional storm events had triggered their formation (Lindhorst et al. 2008). Such transgressive dune fields are common at coasts with low to variable sediment supply but are still poorly understood (Hesp 2013).

A railway track built in 1908 traversed the dune field and became a bike trail after 1970 (crossing the main road and then running south of it; Fig. 2). Since 1935, a road runs parallel to

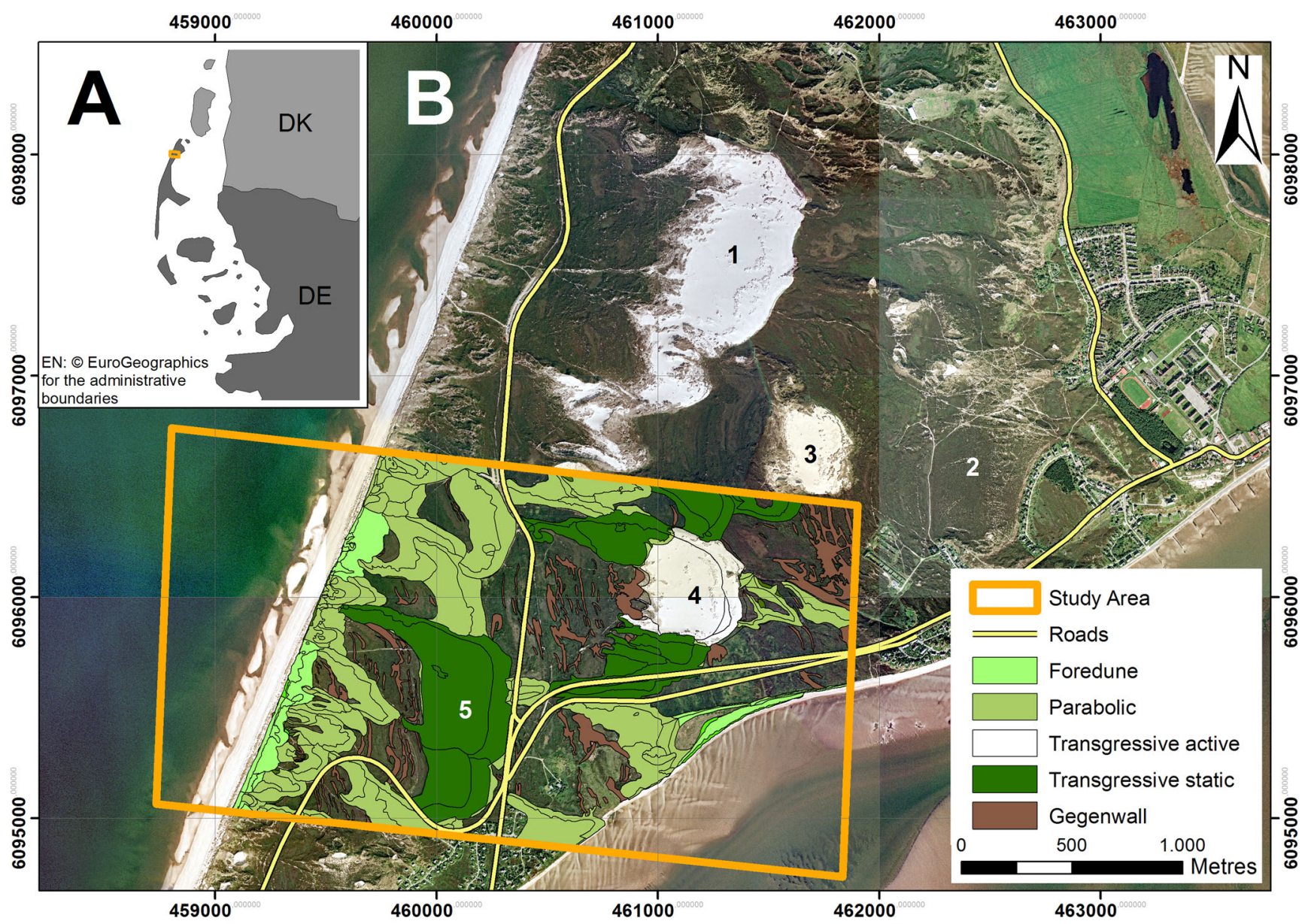

Fig. 2 Location and study area (orange frame) at the northern dune spit of the island of Sylt, between exposed shore (left) and the Wadden Sea (right). Superimposed colour coding is for dune types, and dark shading

within the orange rectangle comprises deflation plains. Inset shows the region of the northern Wadden Sea located in Germany and Denmark, and arrow points to the study area 


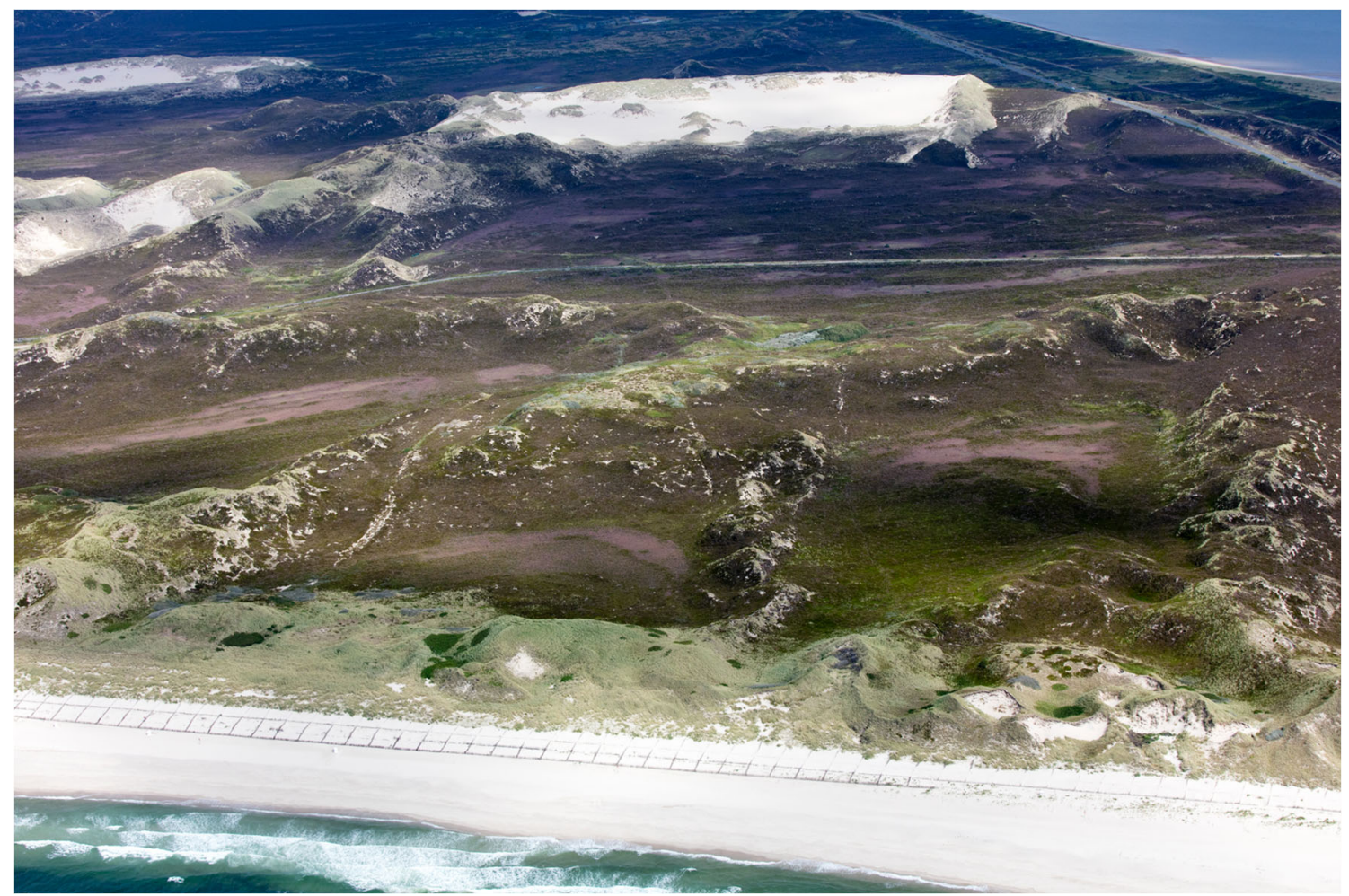

Fig. 3 Aerial view of study area from North Sea (foreground) to Wadden Sea (upper right). At the upper beach, brushwood fences occur in front of foredunes with Ammophila arenaria (light green) and Rosa rugosa (bright green). Dark brown-green indicates heather vegetation of

the beach through the second deflation plain, and since 1965 the present main road branched off eastward, cutting a dune ridge and then running across the third deflation plain (Figs. 2 and 3).

We examined six aerial images from 1936 to 2012 using ArcGIS (ESRI) 10.4.1 for desktop (Table 1). On these images, dune morphology and vegetation types were mapped. The timeline could be partially enlarged by a detailed topographic map from the Prussian mapping programme (Königlich Preußische Landesaufnahme 1878). The dune migration rates were calculated based on the position of the lee slope edge of the migrating dunes in different years with the Digital
Calluna vulgaris and Empetrum nigrum. Moist parts of deflation plains appear in rose (Erica tetralix). White migrant dunes originated near the beach 400 to 500 years ago. Two roads now traverse the transgressive dune area. Photographed by Alex S. MacLean in August 2017

Shoreline Analysis System (DSAS) version 4.4 using linear regression (Thieler et al. 2017).

We distinguished 5 categories of coverage comprising the succession stages from bare sand to dune grasses (mainly marram grass, Ammophila arenaria), heathland (mainly Empetrum nigrum and Calluna vulgaris), scrub or small trees (mainly Rosa rugosa, and species of Populus, Betula, Sorbus, Pinus and Picea) as well as anthropogenic infrastructure.

Dunes were mapped as geomorphological units. Besides the basic dune types (foredune, parabolic dune, transgressive dune and gegenwalle), we focused on erosional features like blowouts, dune cliffs and overwash relics. Embryo dunes hardly

Table 1 Maps and aerial images used for analysing dune morphodynamics and change in vegetation cover. Maps for 1925 and 1965 are from Priesmeier (1970)

\begin{tabular}{llllllllll}
\hline Year & 1878 & 1925 & 27.08 .1936 & Summer 1958 & 1965 & 11.05 .1988 & 22.11 .1998 & 12.09 .2006 & 27.08 .2012 \\
\hline Colour & & & BW & BW & & IR & RGB & RGB & RGB \\
Spatial Resolution & $2,1 \mathrm{~m}$ & $1,1 \mathrm{~m}$ & $0,64 \mathrm{~m}$ & $0,40 \mathrm{~m}$ & $1,1 \mathrm{~m}$ & $0,40 \mathrm{~m}$ & $0,53 \mathrm{~m}$ & $0,50 \mathrm{~m}$ & $0,30 \mathrm{~m}$ \\
Coordinate system used & Bessel 1841 & DHDN & DHDN & DHDN & DHDN & UTM & UTM & UTM & UTM \\
Scale & $1: 25.000$ & $1: 15.000$ & & & $1: 15.000$ & & & &
\end{tabular}

$B W$ Black-White; IR False coloured, including infra-red information; $R G B$ Red-Green-Blue; $D H D N$, Deutsches Haupt-Höhennetz (old system in 1925); UTM, Universal Transverse Mercator 
occur in the area, except as ephemeral Kupsten on active transgressive dunes, which were not considered in the analysis. Single dunes were identified and mapped by transmitting their edges and crests to vector-based GIS shapefiles. For reasons of comparability and orientation during the mapping process, we also adjusted the topographic map from 1878, and the geomorphological maps of 1925 and 1965 provided by Priesmeier \{1970). Further information on dunes and dune vegetation in the survey area by Jessen (1914), Kolumbe (1928), Straka (1963), Heykena (1965), Voigt (1992), Beinker (1996), Panten (2003), and Leguan (2013) were also used in this study.

\section{Results}

\section{Migrant dunes}

Bare sand areas, particularly with large mobile dunes, were dominant at the northern spit of Sylt in 1878 and 1936 (Fig. 4) and presumably in the centuries before. Since the Middle Ages, several villages, including List, have been buried by migrating dunes (Bartels 2013). Since 1878, though, we detected a continuous decrease in bare sand areas, which was most prominent between 1936 and 1988, after which it slowed down, but continued until 2012.

The map from 1878 was merely helpful for descriptive purposes. It did not allow exact calculations of migration rates, though, as dune fronts are represented only very imprecise. From the aerial images from 1936 up to 2012 we were capable to measure a mean migration rate of $2.9 \mathrm{~m} \mathrm{a}^{-1}$ (standard deviation 1.2; dune 1: $2.7 \mathrm{~m} \mathrm{a}^{-1}, \mathrm{SD} \pm 1.4$; dune $3: 3.2 \mathrm{~m} \mathrm{a}^{-1}$, $\mathrm{SD} \pm 1.3$; dune 4: $3.0 \mathrm{~m} \mathrm{a}^{-1}, \mathrm{SD} \pm 0.7$; Fig. 5 and for dune numbers see Fig. 2). Considering also maps from 1878 and 1925 , the overall migration rate is estimated to only $2.2 \pm$ $\left.1.0 \mathrm{~m} \mathrm{a}^{-1}\right)$.

\section{Dune morphology}

Close to the exposed western beach, the decrease of bare sand areas went along with the gradual disappearance of washovers and blowouts (Fig. 6). Apparently, stabilizations of washovers resulted in the formation of a coherent foredune ridge with a retreating dune cliff on the seaward side. Parabolic dunes behind foredunes moved landwards somewhat faster than the
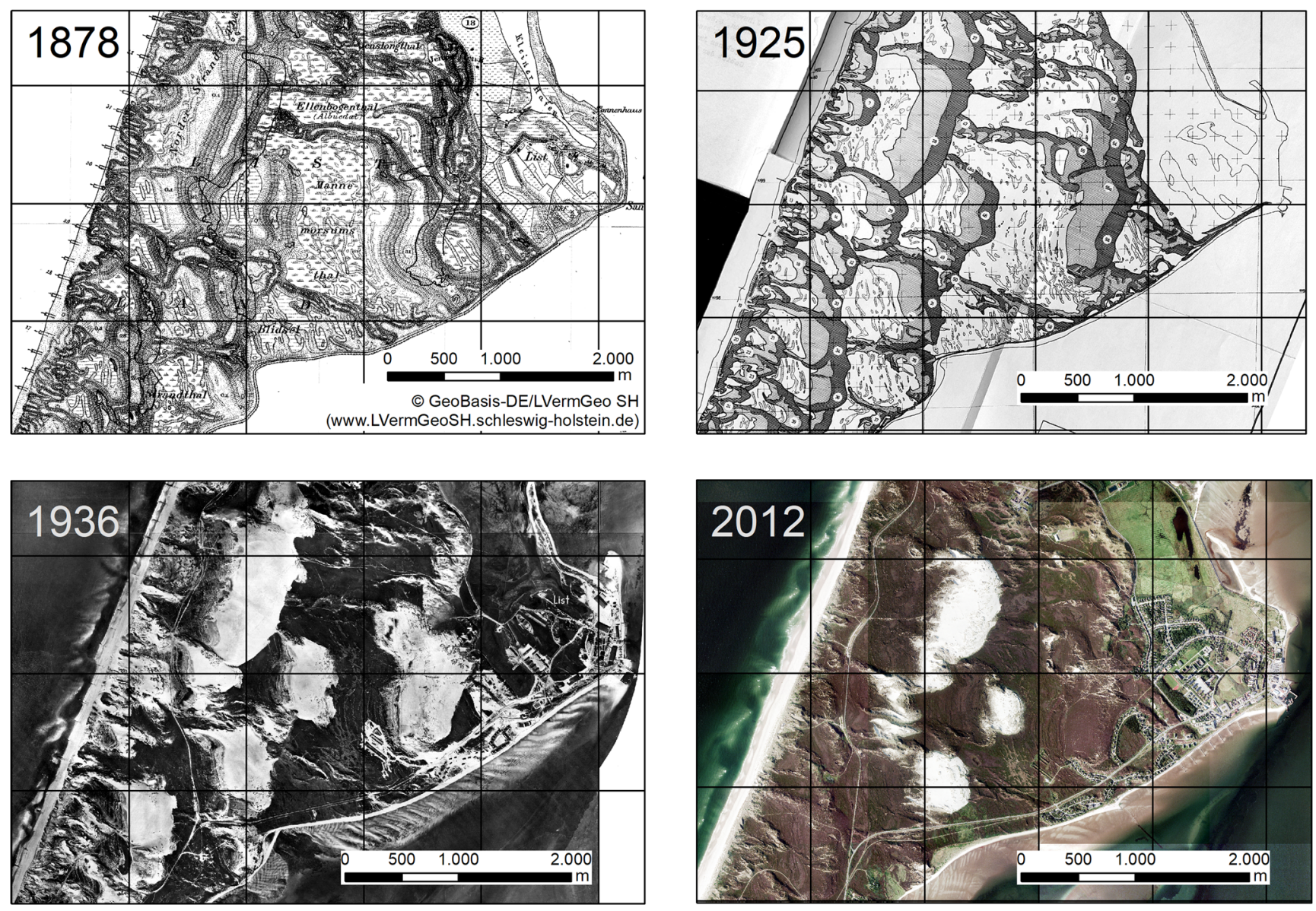

Fig. 4 Maps (1878 and 1925) and aerial photographs (1936 and 2012) of the northern spit of Sylt (named Listland) 
Annual migration rates (m per year; 1878 - 2012)

$\begin{aligned} \square & <1.0 \\ \square & >1.0-1.5 \\ \square & >1.5-2.0 \\ \square & >2.0-2.5 \\ \square & >2.5-3.0 \\ \square & >3.0 \\ \square & \text { Migrating dunes } 1878 \\ \square & \text { Migrating dunes } 2012\end{aligned}$

Dune fronts $1878-2012$

Fig. 5 Annual migration rates of the three remaining mobile dunes between 1878 and 2012

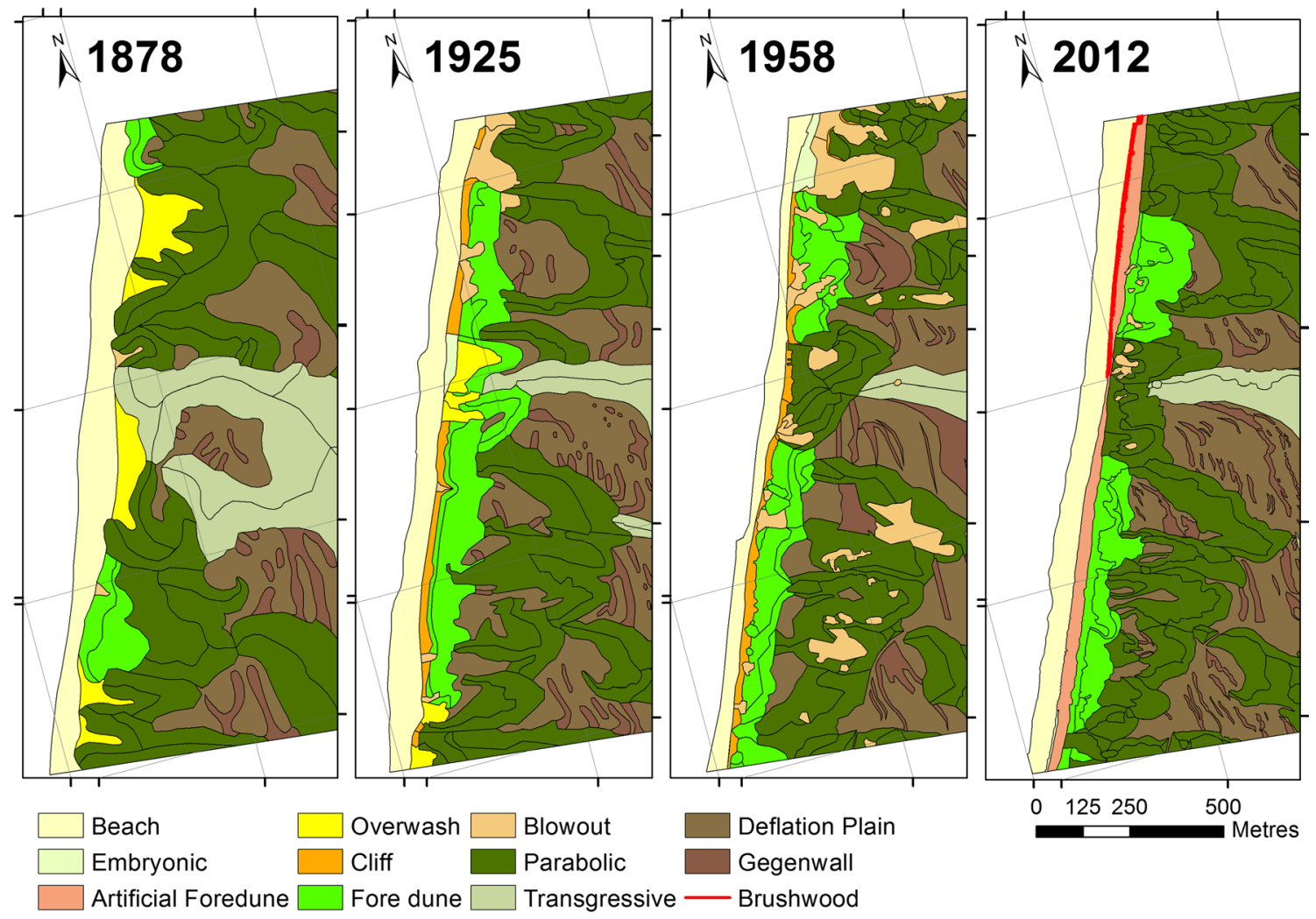

Fig. 6 Change of dune morphology (1878 to 2012) from highly intersected, regressing dunes to a straight cliff and then on to an artificial foredune ridge bolstering the old cliff at the exposed side of the island 
cliff retreated. However, during the second half of the twentieth century, these parabolics ceased to move. At the same time, the dune cliffs shrinked in size, providing less sediment for aeolian transport into the hinterland. Since 1998, a new foredune ridge accumulated in front of the older. A small cliff at the seaward side of the new foredune ridge emerged temporarily within intervals of artificial sand supply. Foredunes behind the passive old cliff continue to move slowly landward, partly covering parabolics on their way.

\section{Vegetation cover}

Bare sand and marram grass cover decreased over time, while heath and high shrubs increased (Fig. 7). The nineteenth century map provides only rough information on the proportions of sand and vegetation. Bare sand areas were apparently dominant in the dune field as a whole. Due to insufficient spectral variations, the image of 1936 only allows an estimate of the extent of bare sand areas. From 1958 onward, quantitative data on all five coverage categories are derived from aerial images. Until 2012, bare sand areas declined from $21 \%$ in 1936 and $12 \%$ in 1958 to $4 \%$. Whereas marram grass declined from $41 \%$ to $13 \%$, heather vegetation increased from $46 \%$ to $77 \%$. Tall shrubs and trees became apparent only in the late twentieth century; in 2012, they covered $4 \%$ of the area.
Around 1880 and 1936, migrating dunes appeared almost completely uncovered. Of these, dunes 2 and 5 as well as others adjacent to the study area (see Figs. 2 and 4) were planted with marram grass in the 1930-40s. Dune 4 had been cut through and stabilized for the railway track early in the twentieth century at the southern trailing ridge, and again after 1965 for a road (Straka and Straka 1984). In that second phase, also the central part of dune 4 was treated with fertilizer, brushwood fences and marram grass planting. However, this had only lasting success close to the new road (Fig. 8). At present, marram grass and crowberry are encroaching this dune (own observation). Thereby, the bare sand area of the mobile dune decreased from 21.6 ha in 1988 to 13.6 ha in 2012. Decreasing bare sand and marram grass gave way to dune heath (mainly Empetrum nigrum and Calluna vulgaris).

\section{Discussion}

About 150 years of dune stabilizations have degenerated a sand conveyor belt of a transgressive dune spit and its potential for adjusting barrier island geomorphology to an accelerating sea level rise. We first discuss the processes of dune aging and its implications, and then add suggestions for the rejuvenation back to a dynamic dune landscape.

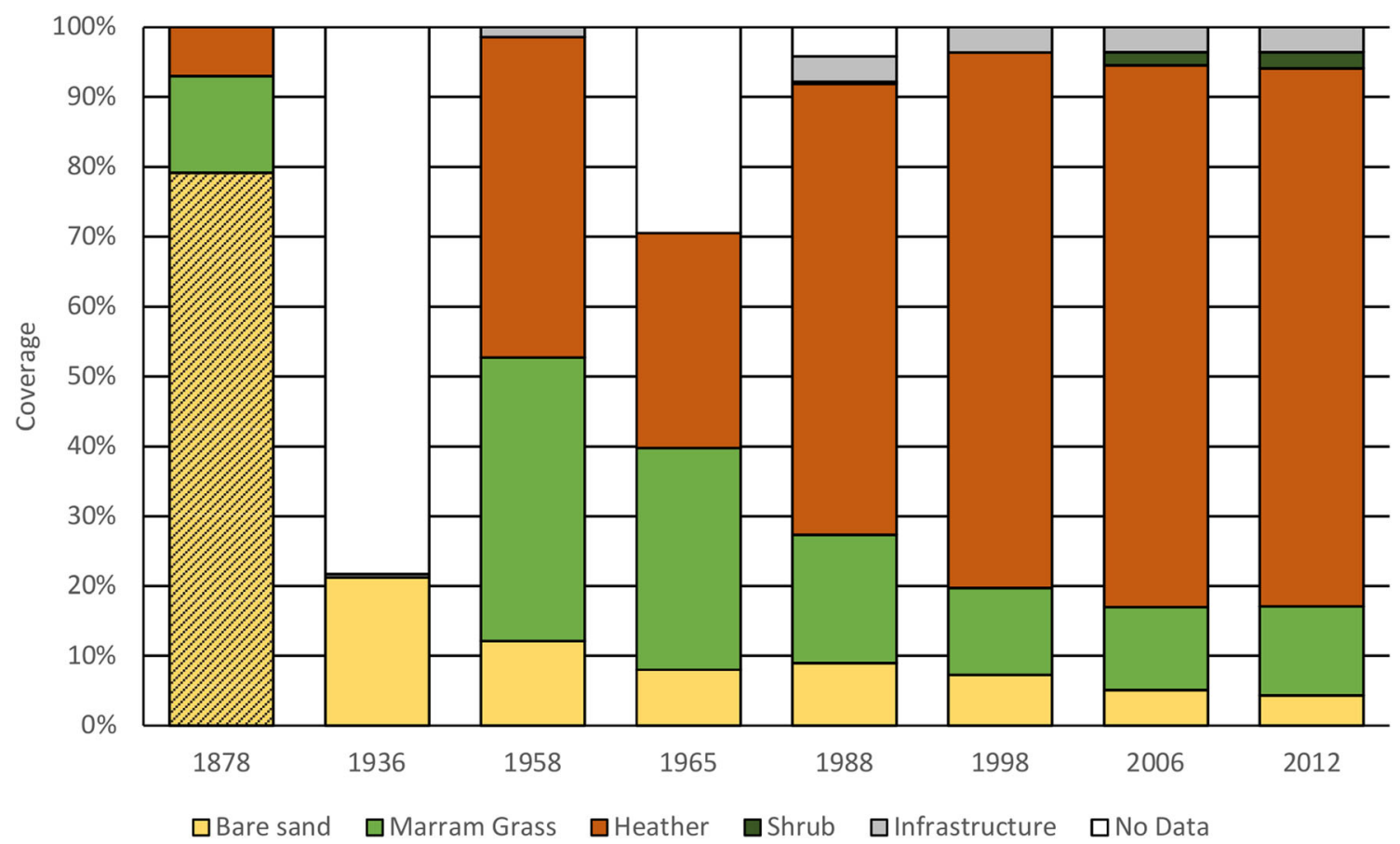

Fig. 7 Change in vegetation cover. 1878: Bare sand in 1878 presumably includes sparse grass cover (shaded area). 1965: Data are from Priesmeier (1970). Deflation planes are not included 


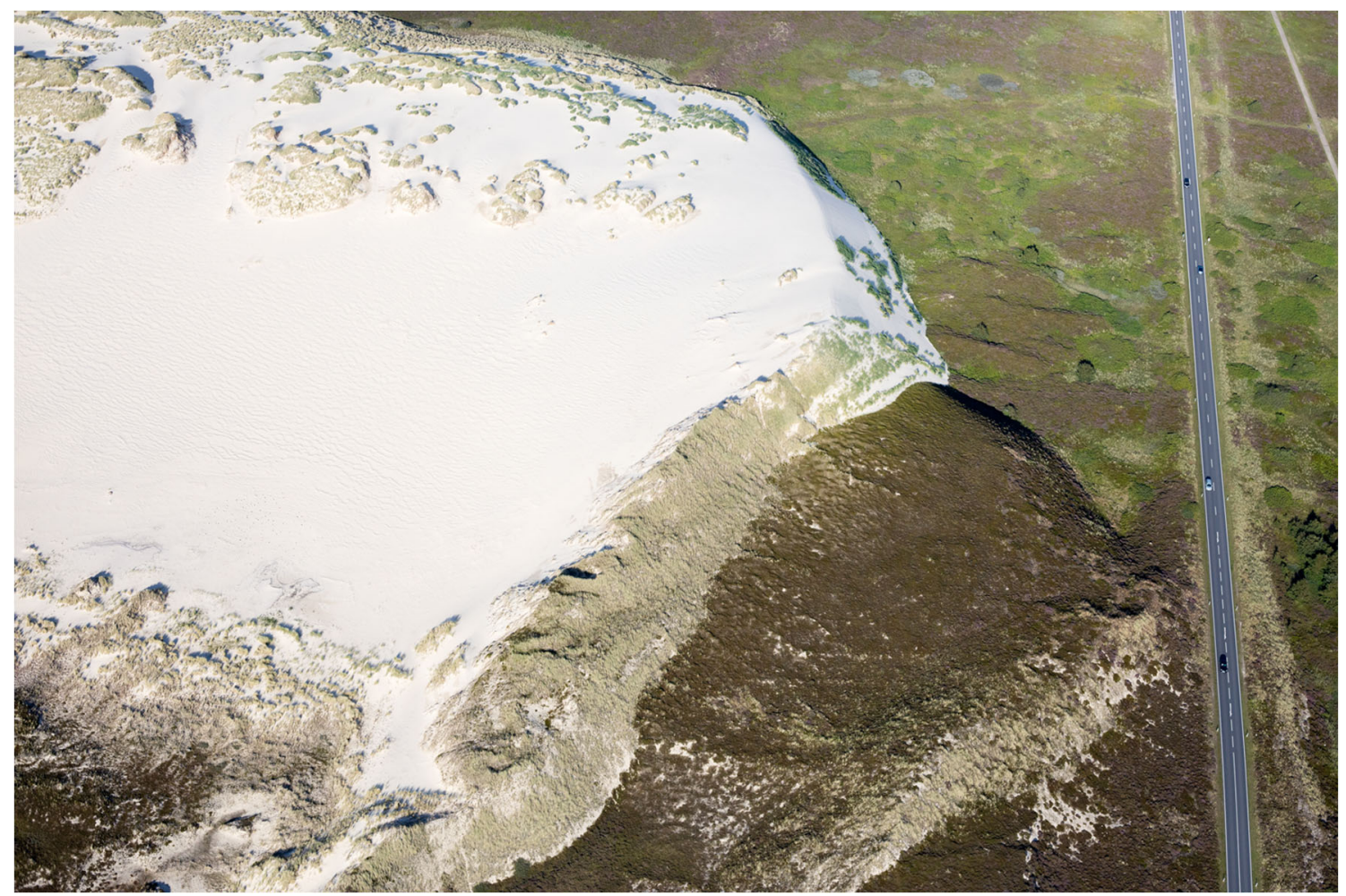

Fig. 8 Mobile dune approaching a road. Dune stabilizations after 1965 were only successful near the road, where succession replaced the planted marram grass by heath (Empetrum and Calluna). The remaining mobile dune is now burying its stabilized part and is heading towards the road again. Photographed by Alex S. MacLean in August 2017

\section{Historical change}

As reviewed by Provoost et al. (2011) for coastal dunes in NW-Europe, a phase of increased dune mobility by overgrazing with livestock and introduced rabbits, wood clearance, harvesting marram grass and cutting sods preceded a reverse phase of increasing dune stability. At many sites, the Little Ice Age supported the trend of general aeolian activity. Since then, aeolian sediment dynamics at many sites have decreased, because of a phasing out of grazing and other uses of dune vegetation, epidemic diseases in rabbits, introducing exotic plants, atmospheric nitrogen deposition, and measures of coastal defence like planting marram grass and pine forests.

A similar environmental history applies to the dune spits of the island of Sylt. A royal decree for dune protection issued already in 1539 , repeat lawsuits over grazing rights, introduction of rabbits in 1732, harvesting of marram grass for fodder and thatching (Fischer 1938; Jessen 1914; Panten 2003) together indicate reduction of dune vegetation until the nineteenth century. Concomitant dune mobility prevailed. Due to nutrient poor acidic soil and dune migrations, no woodland could develop. After the war of conquest by German armies against Denmark in 1864, a war against dune dynamics commenced. Almost all grazing and marram grass harvesting stopped, and washovers and blowouts became precluded by organized plantings of marram grass. Sprawl of military and touristic infrastructures in the dunes were another incentive to stop dune dynamics after 1914.

Our analysis of dune migration and vegetation cover is concerned with the latter phase. Bare dunes near the exposed western shore became stable by building brushwood fences and planting marram grass since the 1860 s as a measure of coastal defence. Where military infrastructures and residential areas were built near mobile dunes, these have been similarly stabilized in the 1930s and 1940s, and occasionally thereafter. These stabilizations account for most of the decrease of bare sand between 1936 and 1958. The subsequent loss of bare sand areas occurred until the 2000s with less direct human interference, like the succession of dune vegetation, its increase in terms of area and, especially, introduced plants.

Large migrant dunes not subjected to planting campaigns continued to move at variable speed. Previous estimates on shorter intervals (Priesmeier 1970; Straka and Straka 1984) are somewhat higher than our averages of 2.2 to $2.9 \mathrm{~m} \mathrm{a}^{-1}$, with or without including old maps, respectively. Comparing the migration rates with other mobile dunes around the North Sea and the Baltic Sea unravels a rather irregular pattern. For the large Danish mobile dune 'Råbjerg Mile' Anthonsen et al. (1996) have calculated higher annual migration rates of 11 to $13 \mathrm{~m}$. On the other hand, Labuz et al. (2018) mention that the Polish mobile dune 'Lacka' close to Leba merely proceeds with 1 to $2 \mathrm{~m}$ annually. Besides methodological differences, 
arguably, each transgressive dune field has its own distinct characteristics. Hesp (2013) considers a complex interplay of multiple factors, which in turn determine the migration speed of single dunes. Furthermore, individual dune migration may vary in multi-annual cycles: Years of slow migration occur when westerly winds primarily increase dune height. This gradually creates steep slip faces, which advance fast by sand avalanches (Priesmeier 1970; Jakob 2014). These avalanches eventually decrease dune height again and dune migration slows down. Length of phases may depend on storms and precipitation (own observations).

Washovers and blowouts in the vicinity to the exposed beach gradually disappeared. We attribute this to stabilization efforts of coastal engineering. In addition, the building of access paths to the beach, fences and information signs helped preventing people from trampling on dune vegetation from the 1970s onward (Klug and Klug 1998; own observations).

Later, repeated sand nourishments (4 times between 1992 and 2016; www.schleswig-holstein.de) at this beach generated a new foredune ridge in front of the cliff, bolstering it and turning it passive. Sand nourishments reversed former beach and dune erosion into dune aggradation, as they substantially increased sediment availability. However, a higher sediment flux from the beach to the hinterland did not occur. Instead, the added sand formed ephemeral embryonic dunes and brushwood trapped sand to form a new foredune ridge, further stabilized by planted marram grass. Therefore, the artificial sand supply does not reach the transgressive dune field in the hinterland. Similar observations have been made at the so-called sand motor at the Dutch coast, where a new foredune acted as a sediment trap (Arens 2015).

\section{Natural succession versus anthropogenic decline in dune dynamics}

Our result, that bare sand and marram grassland areas declined while heath became dominant in the dunes, may be the outcome of natural succession in nutrient poor and acidic dune sand (de Groot et al. 2017a). Also Hesp (2013) describes a large-scale overall trend of transgressive dune fields to stabilize. However, in transgressive dune fields, frequent natural disturbances by waves (washover) and wind (blowouts, migrating dunes) tend to set back plant succession from heath to bare sand. Dunes overgrown with marram grass hold an intermediate position between bare sand and heath. They are still mobile to some extent, driven by wind, and their resilience to wind disturbances is high. Dunes overgrown by heath have become immobile. However, there resilience is low if disturbance initiates a blowout. The deflation widens and on sand deposits at the leeside marram grass takes over (see Hesp et al. 2017). Especially beach erosion and foredune retreat initiate aeolian sediment redistribution (Psuty 2004). Early maps of Sylt support this tendency. Thus, without human interference, dynamic processes with washovers, blowouts and parabolic dune formation near the beach would have prevailed.

We have found, though, that this was not the case (Fig. 9). For dunes on Sylt, there is ample evidence of direct human interference by stabilizing dunes for coastal and infrastructural protection, culminating in the 1940s and still lingering on (see above). This may explain most of the loss of bare sand area and the eventual dominance of heath. However, this does not exclude the role of other facilitating or confounding factors. Grazing by domestic animals stopped around 1970 in our study area but continued in the adjacent dune area to the north. Surprisingly, no difference in vegetation on either side of a fence could be detected (Beinker 1996) and is still not apparent after 40 years (own observation). An explanation may be that sheep in this area can choose between grazing on dune and salt marsh vegetation, and clearly prefer the latter. Variable grazing by rabbits could have had an effect too. Since 1927, a causeway connects the island with the mainland, and a fox population established subsequently. We assume, this excludes rabbits from most dunes and relegates them to residential areas. Due to this timing, vegetation changes that occurred after 1958 (as shown in Fig. 6) cannot be attributed to fading effects of rabbits.

Also there has been no remarkable shift within the regional water regime. The consequences of ongoing climate change such as slightly increasing winter precipitation (DWD 2016) may interact with eutrophication and then facilitate scrub proliferation and grasses (Bakker et al. 2016). This may drive future change in dune vegetation but may not account for changes in the past. Groundwater extraction by wells in the dune field adjacent to our study area occurred from 1936 until 2006 (Petersen 1982; B. König, pers. communication). This might have led to lower groundwater level, while sea level rise would cause it to rise again (Lindhorst et al. 2008). It is unlikely that this affected the vegetation categories in our study.

Instead, increased eutrophication (N-deposition in Fig. 9) accelerates plant succession in nutrient poor and acidic coarse dune sand, where it often results in grass encroachment (Provoost et al. 2011; Veer and Kooijman 1997). In the Wadden Sea region, atmospheric nitrogen deposition increased in the twentieth century until it reached a peak of up to $40 \mathrm{~kg} \mathrm{~N} \mathrm{ha}^{-1} \mathrm{y}^{-1}$ in the $1980 \mathrm{~s}$ and then decreased again. Current values for atmospheric nitrogen deposition in Germany are within a range of $9-12 \mathrm{~kg} \mathrm{~N} \mathrm{ha}^{-1} \mathrm{y}^{-1}$ (de Groot et al. 2017a; Lammerts et al. 2009). Nevertheless, these values still have an impact on dune vegetation. Based on studies from dunes at the Baltic coast, Remke et al. (2009) conclude, that even nutrient inputs as low as $5-8 \mathrm{~kg} \mathrm{~N} \mathrm{ha}^{-1} \mathrm{y}^{-1}$ result in grass encroachment. However, we observed no encroachment with Carex arenaria in our study area (Leguan 2013, own observation).

Arguably, introduced plants constitute a severe indirect human effect on dune succession on Sylt, too (Beinker 1996; 


\section{Dune stabilization}

\section{Sprawl of non-native plants}

\section{Grazing and Trampling}

\section{N-deposition}

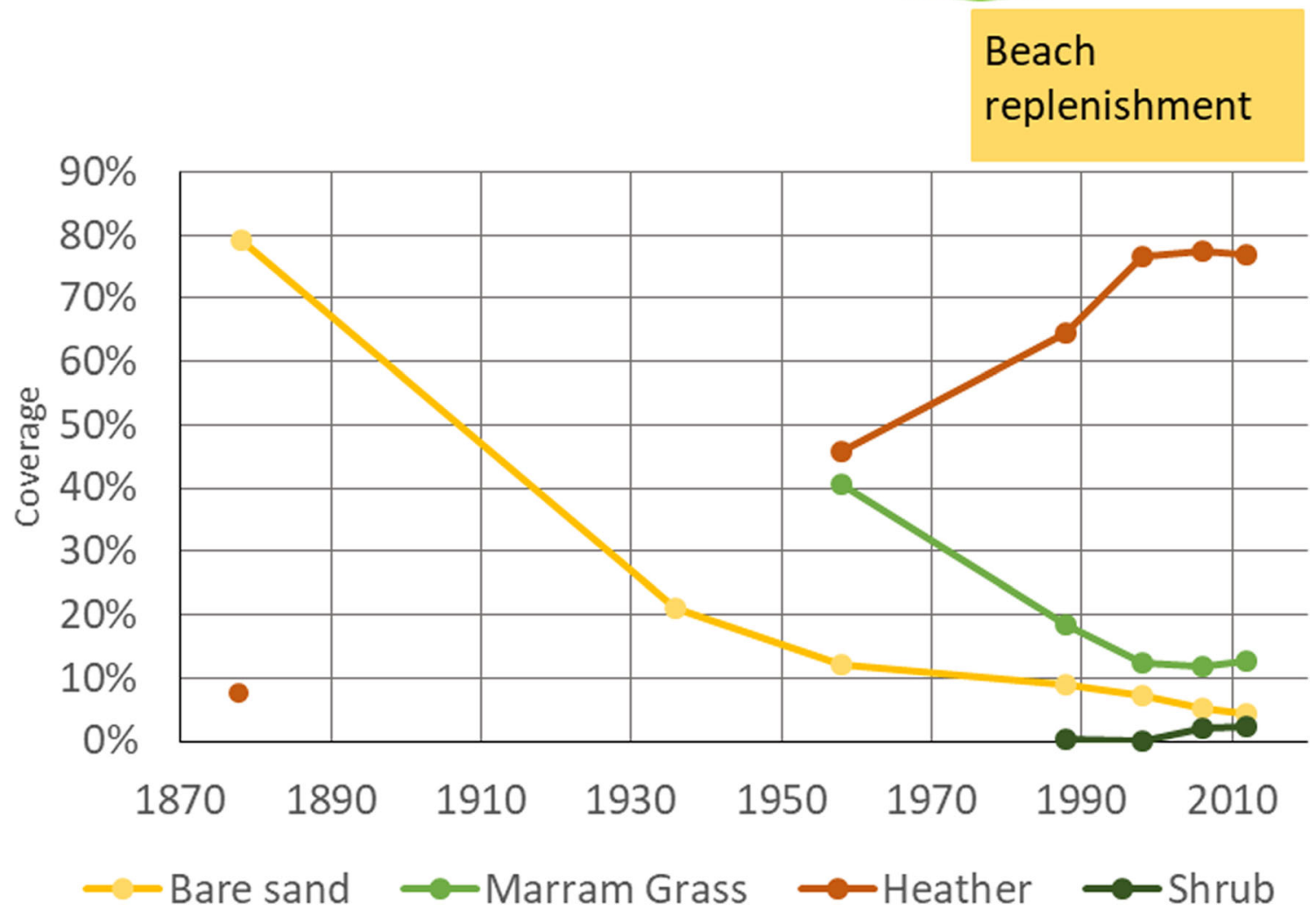

Fig. 9 Varying intensity of anthropogenic effects since the nineteenth century supporting (red) and lowering (green) the natural dune dynamics on the island of Sylt, resulting in declining bare sand area and dominance

Leguan 2013). Particularly from residential areas there is a sprawl of high shrub and trees into the adjacent dunes which is detectable on aerial images. However, most trees (mainly species of Pinus, Picea, Populus, Betula and Sorbus) remain of heath cover. See also the comment on Fig. 7 regarding the bare sand area from 1870 and the text

small and scattered in the dunes up to now. Most prominent are shrubs of Rosa rugosa, occurring at roads and residential areas, at former military infrastructures and on the leeside of foredunes. The latter may be due to beach visitors relieving 
themselves and thus increasing the nitrogen supply for this exotic plant. $R$. rugosa is generally invading dune islands in the Wadden Sea region (Isermann 2008), and on Sylt may cover at least $3 \%$ of total dune area (H. Hoffmann, pers. communication). Another important invader is the heath star moss Campylopus introflexus. In our study area it spread since in the late 1980s and became particularly abundant within grey dune vegetation (Skowronek et al. 2017) and on bare sand areas at the transition between marram grass and heather vegetation (own observation). It contributes to the decline of bare sand, and may facilitate dune stabilization (Essl et al. 2014; Skowronek et al. 2017). We conclude that next to the direct human efforts of dune stabilization, the spread of introduced plants has contributed most to the decline of bare sand and marram grass areas. The overall effect is diminishing habitat diversity and increasing dominance of a few plants at the expense of pioneer species (see also de Groot et al. 2017a, b). The encroachment by high shrubs and trees from residential areas is still at an early stage but is expected to displace characteristic dune vegetation in the long run. Reviving dune dynamics would roll back these long-term trends.

\section{Reviving dune dynamics}

Priesmeier (1970) has documented the wane of the aeolian sediment conveyor belt. Our findings demonstrate that this process has exacerbated since the 1960s. For reasons of nature conservation (de Groot et al. 2017a, b) and long term coastal safety (Oost et al. 2012) this development is detrimental. In the face of accelerating sea level rise in the wake of global warming (Clark et al. 2016; Nerem et al. 2018), traditional strategies for coastal protection require revision. Hofstede and Stock (2018) have outlined a support strategy for tidal flats and salt marshes in the northern Wadden Sea growing with the sea. Similar to coastal wetlands, dune islands should be able again to grow as sea level rises. Pioneering experiments for dune revitalization have already been conducted in The Netherlands (Arens et al. 2013) and in Wales (Pye et al. 2014).

Currently, however, vertical accretion of dune areas is largely impossible due to all the former coastal protection measures still in place (Oost et al. 2012). Gateways for aeolian sand transport across barrier islands will be necessary for stimulating aggradation and resilience in response to an accelerating sea level rise. On crowded recreational islands such as Sylt, dune dynamics adjusting deflation plains to a rising sea and the build-up of new massive dunes surely will cause conflicts with existing infrastructures including residential areas and roads. Furthermore, debates will emerge that may resemble those on managed coastal realignment (i.e., Ahlhorn 2018; Schernewski et al. 2018). New strategies in dune management would constitute a substantial policy change. To gain experience and knowledge, Huitema et al. (2011) stress the importance of pilot experiments. Furthermore, the success should become visible locally before a general paradigm shift is ripe for acceptance.

\section{Suggestion for two pilot experiments}

As a pilot site, we suggest the investigated transgressive dune field which is merely dissected by two roads (Figs. 2 and 3). The residential areas in the vicinity would remain unaffected by reviving dune dynamics. Successful aeolian sand transfer from the exposed beach to the backshore dunes will depend (1) on the amount and frequency of nourished sand to the beach, (2) on local dune topography, and (3) the vagaries of wind, rain and other weather conditions, storm surges in particular.

The aim of the experiment is to initiate parabolic dunes moving inland from the beach with the prevailing wind. Formation and landward migration of parabolics will depend on perpetual supply of sand from the shoreface. This also requires repeated sand nourishments to the beach. In the selected corridor, these parabolics could migrate for two to three centuries before approaching the first road. They would probably fuse with formerly stabilized dunes on their route (see Fig. 3), and then could form a new migrant dune in the far future, progressing with higher speed across the island. The deflation plain left behind it would increase in elevation as groundwater level rises in concert with sea level rise (Lindhorst et al. 2013). Besides preventing nourished sand from being washed back to the sea again, mobile dunes thus raise the elevation of barrier islands, adjusting them to the level of the sea.

At the selected corridor, safety is not at risk and stabilizations of dunes are possible at any time if that would deem necessary. Nourishments have already occurred since the 1990s at this site. However, we endorse shortening intervals and increasing the supply of sand in an effort to initiate substantial aeolian sand movement in backshore direction. Therefore, existing brushwood fencing and planting of marram grass in the foredunes should stop. If storm surges cause washovers, this would facilitate landward sand transport and thus be appreciated. Nevertheless, an immediate success is not certain, and the experimentally increased sand nourishments should continue over a decade or more.

Secondly, we suggest examining to what extent migrating dunes can be reconciled with existing infrastructure. Our study site offers a suitable location for that purpose, too. Since 1965, a main road runs alongside one of the last migrating dunes (Fig. 8). Next to that road the dune (No. 4 in Fig. 2) was stabilized for protecting the nearby road. In the meantime, the still mobile part has been overtaking the formerly stabilized part. Thereby the dune gained in height and now is turning towards the road. Instead of (partially) stabilizing this dune once more, we now suggest to examine another solution in detail: A tunnel for the traffic could allow the dune to pass over the road and proceed to the sheltered beach. Maybe that would be the first time of building a tunnel before a mountain appears. 
For a long-term adjustment of the barrier spit to the expected sea level rise, more than a narrow corridor would be necessary. In the meantime, this pilot project could provide experience with proper management, and then could serve as a vivid example needed for societal choices. This will not only concern financial implications when dunes approach roads or even residential areas but also trade-offs between e.g. shortterm benefits and long-term debts.

\section{Conclusions}

During the last 150 years, dune dynamics have rapidly faded on the island on Sylt. We attribute the long-term increase of heather and other shrub vegetation typical for aging dunes at the expense of bare sand and marram grass areas typical for dune mobility on a barrier island in NW-Europe to dune stabilization measures aggravated by introduced plants. Additionally, the sediment conveyor belt of migrating dunes has been waning. For the sake of nature conservation and long-term coastal safety this state is undesirable. To revert this habitat degeneration and to adapt a barrier island to accelerating sea level rise, we recommend a revitalization of dune dynamics rather than continuing with a static protection strategy. To gain experience with dynamic forms of dune management we suggest two pilot experiments: Finding ways of initiating new parabolic dunes at the exposed western beach, and reconciling migrating dunes with human infrastructure on a crowded tourist island.

Acknowledgements First of all, we thank the anonymous reviewer for the valuable and helpful comments. We express our gratitude to the Coastal Protection Board of Schleswig-Holstein (Landesbetrieb für Küstenschutz, Nationalpark und Meeresschutz des Landes Schleswig Holstein) for providing the aerial images from 1936 and 1958. We thank Alex S. MacLean for his photographs (Figs. 3 and 8). Our special thank goes to Martin Stock who supported this study with data on current vegetation. Furthermore, we should like to thank Bernd König from the Environmental Protection Agency (Landesamt für Landwirtschaft, Umwelt und ländliche Räume des Landes Schleswig-Holstein) who contributed valuable information about the history of groundwater extraction on Sylt.

Open Access This article is distributed under the terms of the Creative Commons Attribution 4.0 International License (http:// creativecommons.org/licenses/by/4.0/), which permits unrestricted use, distribution, and reproduction in any medium, provided you give appropriate credit to the original author(s) and the source, provide a link to the Creative Commons license, and indicate if changes were made.

\section{References}

Ahlhorn F (2018) Integrated coastal zone management: status, challenges and prospects. Wasser. Springer Fachmedien Wiesbaden, Wiesbaden, s.l.
Ahrendt K, Thiede J (2002) Naturräumliche Entwicklung Sylts Vergangenheit und Zukunft. In: Daschkeit A, Schottes P (eds) Klimafogen für Mensch und Küste am Beispiel der Nordseeinsel Sylt. Springer, Berlin, Heidelberg, New York, pp 69-112

Anthonsen KL, Clemmensen LB, Jensen JH (1996) Evolution of a dune from crescentic to parabolic form in response to short-term climatic changes: Råbjerg mile, Skagen Odde, Denmark. Geomorphology 17:63-77. https://doi.org/10.1016/0169-555X(95)00091-I

Arens SM (2015) Dynamic front dune management in the Netherlands. In: Geelen LHWT, Salman A, Kuipers M (eds) Dynamic dunes 2015. Daring solutions for Natura 2000 challenges, p 5

Arens SM, Mulder JPM, Slings QL, Geelen LHWT, Damsma P (2013) Dynamic dune management, integrating objectives of nature development and coastal safety: examples from the Netherlands. Geomorphology 199:205-213. https://doi.org/10.1016/j.geomorph. 2012.10.034

Bakker JP, Baas ACW, Bartholdy J, Jones L, Ruessink G, Temmerman S, van de Pol M (2016) Environmental impacts - coastal ecosystems. In: Quante M, Colijn F (eds) North Sea region climate change assessment, vol 44. Springer International Publishing, Cham, pp 275 314

Bartels M (2013) Die Wanderdünen auf Sylt. Von der Bekämpfung bis zum Schutz eines Naturphänomens. In: Collet D, JakubowskiTiessen M (eds) Schauplätze der Umweltgeschichte in SchleswigHolstein. Werkstattbericht. Univ.-Verl, Göttingen, pp 17-28

Beinker O (1996) Zur Vegetationskunde der Dünen im Listland der Insel Sylt. Kieler Notizen zur Pflanzenkunde in Schleswig-Holstein und, Hamburg, pp 128-166

Bird ECF (1987) The modern prevalence of beach erosion. Mar Pollut Bull 18:151-157

Clark PU, Shakun JD, Marcott SA, Mix AC, Eby M, Kulp S, Levermann A, Milne GA, Pfister PL, Santer BD, others (2016) Consequences of twenty-first-century policy for multi-millennial climate and sealevel change. Nat Clim Chang 6:360-369

Döring M, Ratter B (2018) The regional framing of climate change: towards a place-based perspective on regional climate change perception in north Frisia. J Coast Conserv 22:131-143. https://doi.org/ 10.1007/s11852-016-0478-0

DWD (2016) Nationaler Klimareport 2016, 2. korrigierte Auflage, Offenbach am Main

Essl F, Steinbauer K, Dullinger S, Mang T, Moser D (2014) Little, but increasing evidence of impacts by alien bryophytes. Biol Invasions 16:1175-1184. https://doi.org/10.1007/s10530-013-0572-2

Fischer D (1938) Sylt. In: Müller F (ed) Das Wasserwesen an der schleswig-holsteinischen Nordseeküste. Dietrich Reimer, Berlin

Gripp K, Simon G (1940) Untersuchungen über den Aufbau und die Entstehung der Insel Sylt - 1. Nord Sylt Westküste:24-70

de Groot AV, Janssen GM, Isermann M, Stock M, Glahn M, Elschot K, Hellwig U, Petersen J., van Duin W., Körber P, Jensen K, Hecker N (2017a) Beaches and Dunes. In: Kloepper S (ed) Wadden Sea Quality Status Report 2017, Wilhelmshaven (Germany)

de Groot AV, Oost AP, Veeneklaas RM, Lammerts EJ, van Duin WE, van Wesenbeeck BK (2017b) Tales of island tails: biogeomorphic development and management of barrier islands. J Coast Conserv 21: 409-419. https://doi.org/10.1007/s11852-016-0446-8

Hesp PA (2013) Conceptual models of the evolution of transgressive dune field systems. Geomorphology 199:138-149. https://doi.org/ 10.1016/j.geomorph.2013.05.014

Hesp PA, Hilton M, Konlecher T (2017) Flow and sediment transport dynamics in a slot and cauldron blowout and over a foredune, Mason Bay, Stewart Island (Rakiura), NZ. Geomorphology 295: 598-610. https://doi.org/10.1016/j.geomorph.2017.08.024

Heykena A (1965) Vegetationstypen der Küstendünen an der östlichen und südlichen Nordse. Mitteilungen AG Floristik Schleswigholstein und Hamburg 
Hofstede JLA, Stock M (2018) Climate change adaptation in the Schleswig-Holstein sector of the Wadden Sea: an integrated state governmental strategy. J Coast Conserv 22:199-207. https://doi. org/10.1007/s11852-016-0433-0

Huitema D, Lebel L, Meijerink S (2011) The strategies of policy entrepreneurs in water transitions around the world. Water Policy 13: 717-733. https://doi.org/10.2166/wp.2011.107

Isermann M (2008) Expansion of Rosa rugosa and Hippophaë rhamnoides in coastal grey dunes: effects at different spatial scales. Flora - Morphology, Distribution, Functional Ecology of Plants 203: 273-280. https://doi.org/10.1016/j.flora.2007.03.009

Jakob H (2014, unpublished) The impact of weather on morphology and development of migrating dunes on the Island of Sylt, Master thesis, University of Kiel

Jessen O (1914) Morphologische Beobachtungen in den Dünen vom Amrum, Sylt und Röm. Landeskundliche Forschungen, herausgegeben von der Geographischen Gesellschaft München

Klug A, Klug H (1998) Naturraumbelastung durch den Fremdenverkehr im Norden Sylts. In: Kohlus J, Kiper H (eds) Nordfriesisches und Dithmarscher Wattenmeer, vol 1. Ulmer, Stuttgart, pp 184-185

Kolumbe E (1928) Das Naturschutzgebiet Lister Land auf Sylt. Nordelbingen:455-479

Königlich Preußische Landesaufnahme (1878) List (Insel Sylt). Kreis Tondern. In: Regierungsbezirk Schleswig. Königlich Preußische Landesaufnahme, Berlin

Labuz TA, Grunewald R, Bobykina V, Chubarenko B, Česnulevicius A, Bautrenas A, Morkunaite R, Tonisson H (2018) Coastal dunes of the Baltic Sae: a review. Quaestiones Geographicae 37:47-71. https:// doi.org/10.2478/quageo-2018-0005

Lammerts EJ, Petersen J, Hochkirch A (2009) Beaches and dunes. Thematic Report No. 15. In: Marencic H, Vlas Jd (eds) Quality Status Report 2009. WaddenSea Ecosystem No. 25., Wilhelmshaven (Germany)

Leguan (2013) Kartierung der Salzwiesen und Dünen in SchleswigHolstein/Deutschland 2011-2012. Auftraggeber: Landesbetrieb für Küstenschutz, Nationalpark und Meeresschutz Schleswig Holstein (LKN), Tönning

Lindhorst S, Betzler C, Hass HC (2008) The sedimentary architecture of a Holocene barrier spit (Sylt, German bight): swash-bar accretion and storm erosion. Sediment Geol 206:1-16. https://doi.org/10.1016/j. sedgeo.2008.02.008

Lindhorst S, Betzler C, Hass CH (2013) Large scale architecture of a stacked Holocene spit-the stratigraphy of northern Sylt (southern North Sea)[Großmaßstäbliche Architektur eines holozänen Nehrungshakens-die Stratigrafie von Nord-Sylt (südliche Nordsee).]. Z Dtsch Ges Geowiss 164:63-79. https://doi.org/10. 1127/1860-1804/2013/0001

Martínez ML, Hesp PA, Gallego-Fernández JB (2013) Coastal dune restoration: trends and perspectives. Chapter 20. In: Martínez ML, Gallego-Fernández JB, Hesp PA (eds) Restoration of coastal dunes. Springer, Heidelberg, pp 323-334

Nerem RS, Beckley BD, Fasullo JT, Hamlington BD, Masters D, Mitchum GT (2018) Climate-change-driven accelerated sea-level rise detected in the altimeter era. Proc Natl Acad Sci U S A 115: 2022-2025. https://doi.org/10.1073/pnas.1717312115

Oost AP, Hoekstra P, Wiersma A, Flemming B, Lammerts EJ, Pejrup M, Hofstede JLA, Valk B, der v, Kiden P, Bartholdy J, van der Berg MW, der v, Vos PC, Vries S, Wang ZB (2012) Barrier island management: lessons from the past and directions for the future. Ocean Coast Manag 68:18-38

Panten A (2003) Die Wiederbesiedlung des Listlandes auf Sylt. Nordfriesisches Jahrbuch 39:9-38
Petersen P (1982) Untersuchung über die Grundwasserverhältnisse im Inselkern von Sylt. Landesamt f. Wasserhaushalt u. Küsten Schleswig-Holstein, Kiel

Priesmeier K (1970) Form und Genese der Dünen des Listlandes auf Sylt. Schriften des naturwissenschaftlichen Vereins für SchleswigHolstein 40:11-51

Provoost S, Jones LM, Edmondson SE (2011) Changes in landscape and vegetation of coastal dunes in Northwest Europe: a review. J Coast Conserv 15:207-226. https://doi.org/10.1007/s11852-009-0068-5

Psuty NP (2004) In: Martínez ML, Psuty NP (eds) Coastal dunes: Ecology and conservation; with 33 tablesThe coastal foredune: a morphological basis for regional coastal dune development. Springer, Berlin, pp 11-25

Psuty NP, Silveira TM (2013) Restoration of coastal Foredunes, a geomorphological perspective: examples from New York and New Jersey, USA. Chapter 3. In: Martínez ML, Gallego-Fernández JB, Hesp PA (eds) Restoration of coastal dunes. Springer, Heidelberg, pp 33-48

Pye K, Blott SJ, Howe MA (2014) Coastal dune stabilization in Wales and requirements for rejuvenation. J Coast Conserv 18:27-54

Remke E, Brouwer E, Kooijman A, Blindow I, Roelofs JGM (2009) Low atmospheric nitrogen loads Lead to grass encroachment in coastal dunes, but only on acid soils. Ecosystems 12:1173-1188. https://doi. org/10.1007/s10021-009-9282-0

Schernewski G, Bartel C, Kobarg N, Karnauskaite D (2018) Retrospective assessment of a managed coastal realignment and lagoon restoration measure: the Geltinger Birk, Germany. J Coast Conserv 22:157-167. https://doi.org/10.1007/s11852-017-0496-6

Skowronek S, Ewald M, Isermann M, van de Kerchove R, Lenoir J, Aerts R, Warrie J, Hattab T, Honnay O, Schmidtlein S, Rocchini D, Somers B, Feilhauer H (2017) Mapping an invasive bryophyte species using hyperspectral remote sensing data. Biol Invasions 19: 239-254. https://doi.org/10.1007/s10530-016-1276-1

Straka H (1963) Über die Veränderungen der Vegetation im nördlichen Teil der Insel Sylt in den letzten Jahrzehnten. Schriften des naturwissenschaftlichen Vereins für Schleswig-Holstein 34:19-43

Straka G, Straka H (1984) Über die Veränderung der Vegetation irn nördlichen TeiI der lnsel Sylt (NSG Nord-Sylt) von 1960 bis 1982. Schr. Naturwiss. Ver. Schleswig-Holstein:1-17

Thieler ER, Himmelstoss EA, Zichichi JL, Ayhan E (2017) Digital Shoreline Analysis System (DSAS) version 4.4 - An ArcGIS extension for calculating shoreline change: U.S. Geological Survey OpenFile Report 2008-1278. https://pubs.er.usgs.gov/publication/ ofr 20081278

Veer MAC, Kooijman AM (1997) Effects of grass-encroachment on vegetation and soil in Dutch dry dune grasslands. Plant Soil 192:119 128

Voigt H (1992) Die Festung Sylt: Geschichte und Entwicklung der Insel Sylt unter militärischem Einfluss 1894-1945. Nordfriisk Instituut, vol 109. Verl. Nordfriisk Inst, Bräist/Bredstedt

Zhang K, Douglas B, Leatherman SP (2004) Global warming and coastal Erosion. Clim Chang 64:41-58

Publisher's note Springer Nature remains neutral with regard to jurisdictional claims in published maps and institutional affiliations. 